\title{
APPLYING ECONOMIC GUIDELINES FOR RESPONSIBLE TOURISM IN A World Heritage Site
}

\author{
WILLEM J. L. COETZEE \\ MATHILDA VAN NIEKERK \\ Department of Tourism Management \\ Tshwane University of Technology \\ South Africa \\ MELVILLE SAAYMAN \\ Institute for Tourism and Leisure Studies \\ North-West University (Potchefstroom Campus) \\ South Africa \\ Correspondence to: Willem J. L. Coetzee \\ e-mail: coetzeewjl@tut.ac.za \\ Postal Address: Private Bag X680, Pretoria, 0001, South Africa
}

\begin{abstract}
This article proposes an integrated sustainable tourism development strategy for the Vredefort Dome as a World Heritage Site. In particular, it analyses the integration of the South African guidelines for responsible tourism applied to a local community. All tourism product owners in the Dome area formed part of this research that was conducted by means of a survey. The strategy that was formulated for the area aims to ensure that future generations will be able to utilise the resources in the same manner as the present generation. It is indicated that this intra-generational equity will only be possible through an integrated approach. The value of this research is its contribution to responsible tourism and, concurrently, its emphasis on the fact that tourism destinations in South Africa need to be developed in an integrated and sustainable manner.
\end{abstract}

In order for the Vredefort Dome to be a World Heritage Site, and to exist as a protected area, it is imperative that the tourism product owners in the area realise their roles as custodians of this precious site. This proposition leads to the main aim of this study, namely to develop an integrated tourism development strategy for the Vredefort Dome as a World Heritage site.

The results of the empirical study indicated that tourism stakeholders are prepared to improve the present situation in the Vredefort Dome and are willing to adjust their business practices in the future. Such changes in practice involve some strategic issues, and the economic, social and environmental strategies will give direction to this World Heritage Site to become more sustainable.

Keywords: tourism, sustainable guidelines, integrated development, World Heritage Site, Vredefort Dome

This study focuses on the tourism stakeholders and their economic responsibility regarding sustainable tourism in the rural area of the Vredefort Dome. The South African guidelines for responsible tourism (social, environmental and economic) were used in the research although only the economic guidelines for responsible tourism will be reflected in this article. These guidelines were used to evaluate the present state of affairs and the stakeholders then had to predict the future importance of each guideline. Based on the effect sizes, the most important aspects (according to the stakeholders) are that they will maintain and encourage social and cultural diversity as well as assess the economic impacts, as a prerequisite to developing tourism in the area.

Rural communities such as the Vredefort Dome (see Figure 1) usually have few resources that can be developed, and because of this many communities are currently examining nontraditional means for economic diversification. In the Vredefort Dome it is, however, not a lack of natural resources that poses a problem - because the tourism potential of this area is well documented (IIED, 2000; Contour, 2002). According to Reimold and Coney (2001) more than seven hundred publications have appeared with some reference to the majestic Vaal River and the scenic Vredefort Hills. It is for this reason that local policy-makers in rural communities such as this one realise the importance of tourism. Although they have little or no experience regarding the development of tourism, many have nonetheless already grasped at opportunities for tourism development. However, do communities consider and monitor the effects of such development? A segment of the community in the Vredefort Dome has realised the importance of tourism, but it can be argued that there is a lack of integrated planning in this regard. According to Briedenhann and Wickens (2004), the lack of a strategic tourism plan in order to develop tourism in a sustainable manner, and also to alleviate poverty, is a general point of concern.

The aim of this article is to report on current tourism practices in the Vredefort Dome area and to predict future practices in terms of the following:

- Economic impacts as a prerequisite to developing tourism in the area

- Willingness to maximise local economic benefits by increasing linkages and reducing leakages

- Ensuring that the community is involved in, and benefits from, tourism

- Responsible marketing and product development in the VFD

- Equitable business opportunities in the VFD

\section{LITERATURE REVIEW}

Authors such as Inskeep (1991) have provided examples of how unfettered tourism growth can lead to detrimental impacts on the socio-cultural values of local residents, the economic diversity/development, and the environment. These impacts and their consequences have been discussed by a number of 




authors as relevant in terms of economic growth, job creation, income for local governments (see also Dwyer et al. 2003:431) and catalysts for other sectors such as agriculture, forestry, and fishing (Curtin 2003:173; Finkler \& Higham 2004) and the manufacturing industries, as well as infrastructure development for the local community (Han et al. 2003:153). Early research from other disciplines such as anthropology (Smith 1977), geography and sociology also plays educational roles in the fields of different ideologies, culture, national heritage, the environment, political differences and cross-cultural attitudes towards an integrated development process. Careful assessment and implementation of policy tools to minimise negative impacts on social attributes constitutes an important component of integrative tourism planning in rural settings.

Inskeep (1991) and many others call for integrated tourism planning within a broader regional context. The intent of integrative tourism planning is to provide for tourism development strategies in areas such as the Dome that will be effective in enhancing the social, economic and environmental assets in the region and that simultaneously act to minimise the potential liabilities. By its nature, tourism brings outsiders into a local community. As with other development strategies, this global phenomenon is having a dramatic impact at the local level: some traditional cultures and economies are being modified to the extent that they are effectively destroyed (Routledge 2002). Furthermore, outsiders may eventually decide to move to the local community that once served as their original tourist destination.

The literature in this regard has identified unique processes and methods that are specific to tourism planning (Oliver \& Jenkins 2003:293). Tourism development planning in rural areas has given rise to a growing body of academic literature (MacDonald \& Jolliffe 2003:307). Key unique attributes of more integrative tourism planning approaches include incorporating a broad mix of contemporary issues, initiatives, stakeholders, and objectively based data into the regional planning process. To conclude, this issue calls for a careful approach to tourism development that is integrated with overall regional goals. This approach is founded on Murphey's (1985:176) work on tourism development planning and calls those interested in sustaining rural communities to attention: "Economic problems ... have led many communities to consider embracing this growth industry [tourism] of the post-industrial era."

An integrated sustainable tourism strategy will take into account the social, economic and environmental issues as set out in Agenda 21 - the foundation document of sustainable development. Oliver and Jenkins (2003:293) define integrated tourism as that which is explicitly linked to the localities in which it takes place and, in practical terms, has clear connections with local resources, activities, products, production service industries, and a participatory local community. As Murdoch (1993:225) stated fifteen years ago, the implications of breaking down disciplinary boundaries are far-reaching but necessary to any meaningful research on sustainability.

\section{RESEARCH METHOD}

The population was identified after discussions with the tourism information centre in Parys (the closest town to the Dome) as well as the information centre in nearby Potchefstroom. A list was compiled of all 43 tourism product owners in the Vredefort Dome area. Ten stakeholders $(n=10)$ were identified as stakeholders that provide accommodation only. The majority $(n=21)$ of the respondents belong to the sector that provides accommodation and also act as operators in tourism activities such as rafting, hiking and team building. The hospitality sector comprised only five stakeholders $(n=5)$ and seven $(n=7)$ of the identified stakeholders are shop owners who deal mainly with tourists, for example antique, souvenir, and arts and handcraft shops.

The forty-three questionnaires were hand-delivered in the area with a covering letter explaining the purpose of the study. A follow-up reminder was faxed after seven days to remind the respondents that the questionnaires would be collected the 
following day (eight days after delivery). During the collection phase a follow-up reminder with a copy of the questionnaire was left with each non-respondent to be collected after seven days. Twenty-eight questionnaires were collected, representing an overall response rate of $60 \%$. Two of the questionnaires were discarded because respondents filled in all the "yes" answers in the yes/no category and all the 3's on the Likert scale. Both of these respondents were shop owners and it was clear that they could not agree on all the environmental issues as indicated. Finally, twenty-six questionnaires were used in the statistical analysis $(n=26)$.

Based on the South African guidelines for responsible tourism, a survey questionnaire was developed to examine respondents perceptions regarding the importance of sustainable tourism development and their vision for the future of the Vredefort Dome. In the guidelines for responsible tourism the criteria are divided into three sections: economic aspects, social aspects, and environmental aspects. The scale that was used entailed requesting two answers from respondents, namely:

- A yes/no answer (Yes = in their organisation this guideline is already in practice; $\mathrm{No}=$ in their organisation they do not practice the guideline).

- A Likert three-point scale: $(1=$ not important, $2=$ important and $3=$ very important) to evaluate the view of product owners on how important they feel each aspect will be for the future.

As the guidelines for responsible tourism have already been grouped into 12 subdivisions, it was not possible to perform a factor analysis of data - and furthermore, apart from that, the population that was selected for this study was not substantial enough for such an exercise. For the purpose of this study, therefore, the following formula was used to measure the differences for dependent data (Steyn 2000):

$d=\frac{\bar{x}_{\text {diff }}}{S_{\text {diff }}}$

where $\bar{x}_{\text {diff }}$ is the mean and $s_{\text {diff }}$ the standard deviation of each construct under each of the 12 subsections.

The statistical analysis was performed by the Statistical Consultation Services of North-West University by making use of the $S A S \otimes$-programme (SAS Institute Inc. 2001).

\section{RESULTS OF THE FREQUENCY ANALYSIS REGARDING ECONOMIC ASPECTS}

The results of frequency analysis regarding economic issues will be addressed under the following five methodological subsections:

- Assessing economic impacts as a prerequisite to developing tourism in the VFD

- Maximising local economic benefits -increasing linkages and reducing leakages

- Ensuring that the community is involved in, and benefits from, tourism

- Marketing and product development in the VFD

- Equitable business opportunities in the VFD

The discussion of each of the above five subsections is structured in a table that indicates the present situation (if tourism stakeholders apply the guidelines at present) as well as a future perspective (how important the guidelines will be in the future). Both the present and the future perspectives are ranked according to importance $(1=$ the most important) in order to provide a clear indication of how priorities will change from the present towards a strategic future perspective.

\section{Assessing economic impacts as a prerequisite to developing} tourism in the VFD

From the literature it is clear that economic impacts are important in order to maximise the positive impacts of tourism and to minimise the negative ones. From Table 1 it is clear that product owners recognise that tourism can create revenue from cultural heritage, traditional ways of life, wildlife and habitats (1.1.3) and they rated this aspect as the most important at present. To exercise a preference for business that directly benefits the local community (1.1.8) was rated second, which means that most of the product owners support local businesses. An interesting fact is that the product owners identified the historically disadvantaged as an emerging domestic tourism market (1.1.2).

Currently the product owners do not regard it as important to consider the adverse effects of tourism such as local land price inflation, and/or loss of access to resources (1.1.7), but this guideline is ranked as no.1 for the future. It is clear that the product owners regard this issue as imperative and therefore rated the guideline as the most important. Losses of access to and land price inflation are well documented in the literature, but rural communities are not always aware of the negative impacts; they are rather blinded by the possible economic benefits. This issue needs to be addressed if the VFD would like to leave something of the present for future generations, otherwise the future generations of this area will not be able to enjoy the current way of living. It is a fact that if tourism development is not properly planned and developed it can lead to an increase in land prices and the area runs the risk of losing its unique character. Inskeep (1991:372) states that: "... if residents cannot conveniently use their own facilities, they will become irritated and resentful of tourism".

The following aspects were also rated as important for the future in the VFD: the product owners would encourage business relationships between foreign entrepreneurs and local and emerging entrepreneurs (1.1.4). The product owners also realise that the historically disadvantaged as an emerging domestic tourism market (1.1.2) is an important aspect regarding future success. In 2002, the Department of Environmental Affairs and Tourism (DEAT) embarked on the first national domestic tourism survey to identify existing and potential domestic markets. To exercise a preference for business that directly benefits the local community (1.1.8) will also help to reduce leakage out of the community and will help to spread the economic benefits in the VFD. One point of concern that arises from Table 1 is the fact that the product owners do not regard it as important at present or in the future to plan initiatives and investments to contribute to the broader local economic development strategy of the Dome (1.1.6). After the survey, the economic development forum of the area

TABLE 1

Assessment of economic impacts as a prerequisite when developing tourism

\begin{tabular}{|c|c|c|c|c|}
\hline \multicolumn{2}{|c|}{ PRESENT } & $\begin{array}{c}\text { ASSESSING ECONOMIC IMPACTS AS A PRE- } \\
\text { REQUISITE }\end{array}$ & \multicolumn{2}{|c|}{ FUTURE } \\
\hline \multicolumn{2}{|c|}{0.851276} & \multirow[t]{2}{*}{ Cronbach-alpha coefficient } & \multicolumn{2}{|c|}{0.585067} \\
\hline $\mathbf{R}$ & $\%$ & & $\mathbf{R}$ & $\%$ \\
\hline & 54.69 & $\begin{array}{l}\text { 1.1.1 Extend the tourism season by developing new } \\
\text { products }\end{array}$ & 7 & 19.91 \\
\hline & 59.93 & $\begin{array}{l}\text { 1.1.2 Identify the historically disadvantaged as an } \\
\text { emerging domestic market }\end{array}$ & 3 & 35.47 \\
\hline & 82.47 & $\begin{array}{l}\text { 1.1.3 Recognise that tourism can create revenue from } \\
\text { cultural heritage }\end{array}$ & 6 & 22.40 \\
\hline & 50.06 & $\begin{array}{l}\text { 1.1.4 Encourage business relationships between } \\
\text { foreign entrepreneurs }\end{array}$ & 2 & 41.14 \\
\hline 6 & 49.51 & 1.1.5 Maintain and encourage economic diversity & 5 & 28.23 \\
\hline & 47.20 & $\begin{array}{l}\text { 1.1.6 Plan initiatives and investments to contribute to } \\
\text { local economy }\end{array}$ & 9 & 9.02 \\
\hline 0 & 45.82 & $\begin{array}{l}\text { 1.1.7 Consider adverse effects of tourism such as land } \\
\text { price inflation }\end{array}$ & 1 & 45.62 \\
\hline 2 & 76.18 & $\begin{array}{l}\text { 1.1.8 Exercise a preference for businesses that benefit } \\
\text { the community }\end{array}$ & 4 & 30.32 \\
\hline 0 & 49.51 & $\begin{array}{l}\text { 1.1.9 Conduct market feasibility before raising } \\
\text { expectations }\end{array}$ & 8 & 17.59 \\
\hline
\end{tabular}


employed an economic development officer to facilitate the economic development idea that might lead to an enhanced economic strategy.

\section{Maximising local economic benefits - increasing linkages and reducing leakages}

Two important aspects of economic enhancement programming are firstly, to increase the linkages between tourism and other economic elements, for example agriculture, and secondly, to reduce leakage of money generated in the area. Leakage is the purchasing power that is spent on imports to an area, resulting in a transfer of income out of the local economy (Cook et al. 2002:299). The longer money circulates in the area, the more economic benefits will be generated. The VFD is suitable for becoming a self-sufficient area, and in this way jobs can be generated, which will subsequently lead to economic growth.

In order to achieve a reliable measuring instrument, the following two guidelines were left out of the frequency analysis: (i) to buy locally-made goods and use locally-provided services from locally-owned businesses (1.2.3) and (ii) to cooperate with other formal sector businesses to maximise benefits for local community enterprises (1.2.5). The reason for the inconsistent rating of these two guidelines might be that the guidelines incorporate more than one issue per guideline or that the formulation of these guidelines is not acceptable for statistical analyses. For any future research it would be interesting to see how these two guidelines are rated by respondents.

It is noteworthy that product owners would like to encourage all establishments to upgrade their standards of service and in that way maximise their revenue earning potential (1.2.1). Other communities with similar ideas introduced a local grading system that forced the product owners to register with the local tourism information office, and in return the information office would have an idea of the services offered by different establishments.

An essential and highly rated guideline is that the product owners must help the local community to develop its products so that the products can be more easily used by others (1.2.4). Product development and distribution will lead to higher amounts spent by both tourists and by product owners in the area. This guideline was rated very highly for the future and it is encouraging to see that product owners seem willing to assist the local community with product development.

Give customers the opportunity to purchase locally produced crafts and curios (1.2.6) is an excellent way of generating jobs for the local artists and craftspeople. At present, the product owners feel that they are not doing enough to achieve this guideline, but it is encouraging to see how highly they rate the increase for the future. The VFD is well known for the number of craft shops and the density of artistic activity in the area. The VFD

TABLE 2

Maximising local economic benefits

\begin{tabular}{|c|c|c|c|c|}
\hline \multicolumn{2}{|c|}{ PRESENT } & MAXIMISING LOCAL ECONOMIC BENEFITS & \multicolumn{2}{|c|}{ FUTURE } \\
\hline \multicolumn{2}{|c|}{0.569278} & \multirow[t]{2}{*}{ Cronbach-alpha coefficient } & \multicolumn{2}{|c|}{0.593118} \\
\hline $\mathbf{R}$ & $\%$ & & $\mathbf{R}$ & $\%$ \\
\hline 2 & 55.48 & $\begin{array}{l}\text { 1.2.1 Encourage all establishments to upgrade their } \\
\text { standards }\end{array}$ & 3 & 23.59 \\
\hline \multirow[t]{2}{*}{3} & 27.05 & $\begin{array}{l}\text { 1.2.2 Encourage the informal sector to become part } \\
\text { of the formal sector }\end{array}$ & 4 & 22.43 \\
\hline & N/A & $\begin{array}{l}\text { 1.2.3 Buy locally-made goods and use locally-made } \\
\text { goods }\end{array}$ & & N/A \\
\hline \multirow[t]{2}{*}{1} & 59.72 & $\begin{array}{l}\text { 1.2.4 Help the local community to develop its } \\
\text { products }\end{array}$ & 2 & 52.95 \\
\hline & N/A & $\begin{array}{l}\text { 1.2.5 Cooperate with other formal businesses to } \\
\text { maximise benefits }\end{array}$ & & N/A \\
\hline 4 & 6.63 & $\begin{array}{l}\text { 1.2.6 Give customers the opportunity to purchase } \\
\text { locally }\end{array}$ & 1 & 54.44 \\
\hline
\end{tabular}

artists' community has established an art route, and product owners that elect not to sell local art and handcraft at their establishments can assist by distributing maps of the route. In future, this guideline will help the VFD community to tap into new tourism markets, other than adventure tourism: namely those of art lovers and international craft buyers.

Maximising local economic benefits by increasing linkages and reducing leakages is a complicated issue. For the present and future generations it is essential for product owners to establish an amalgamated strategy without compromising the economic well-being of present establishments. From Table 2 it is encouraging to see where the future increases will occur - in community enhancement and locally produced crafts and curios.

Ensuring that the community is involved in, and benefits from, tourism

Community involvement is an essential element of a successful strategy for sustainable tourism development. The product owners are willing to encourage visitors to spend more money in the local economy, bringing business to the local community (1.3.8) and to encourage tour operators to be more innovative in their itineraries, by, for example, including shebeens, local museums and art galleries (1.3.9). It is clear from the above that the product owners are prepared to encourage tourists to spend more money and to assist tour operators in programme planning. Tour operators are not always aware of secondary attractions in an area and it is hence the responsibility of established product owners to spread the economic benefits. The VFD has established an economic development forum, which is an excellent way to start, so that businesses can become aware of each other and network in the business environment.

The following are ideal guidelines, but an elected person in each organisation in the VFD needs to consider marketing, training and managerial support for promising tourism projects (1.3.6) and the product owners will hopefully consider using local entrepreneurs in developing community initiatives (1.3.10). Some product owners are willing to consider establishing targets to monitor progress in achieving sustainable tourism objectives (1.3.12). The definitions of sustainable development are clear on the fact that it is a futureorientated concept and therefore it is essential that targets or indicators are needed to reach these objectives (Bell \& Morse 1999). Transparency is also important when reporting community

TABLE 3

Community involvement in, and benefit from, tourism

\begin{tabular}{|c|c|c|c|c|}
\hline \multicolumn{2}{|c|}{ PRESENT } & $\begin{array}{c}\text { COMMUNITY INVOLVEMENT IN, AND BENEFIT } \\
\text { FROM, TOURISM }\end{array}$ & \multicolumn{2}{|c|}{ FUTURE } \\
\hline \multicolumn{2}{|c|}{0.846828} & \multirow[t]{2}{*}{ Cronbach-alpha coefficient } & \multicolumn{2}{|c|}{0.848138} \\
\hline $\mathbf{R}$ & $\%$ & & $\mathbf{R}$ & $\%$ \\
\hline 6 & 52.8 & $\begin{array}{l}\text { 1.3.1 Enable the historically disadvantaged to engage } \\
\text { in tourism }\end{array}$ & 11 & 11.35 \\
\hline 2 & 68.2 & $\begin{array}{l}\text { 1.3.2 Work closely with local communities to develop } \\
\text { new products }\end{array}$ & 8 & 43.91 \\
\hline 10 & 36.4 & $\begin{array}{l}\text { 1.3.3 Develop business partnerships in which the } \\
\text { community has a significant stake }\end{array}$ & 4 & 59.63 \\
\hline 3 & 59.9 & 1.3.4 Identify projects that can support the poor & 2 & 82.63 \\
\hline 5 & 57.2 & 1.3.5 Assist in the development of local entrepreneurs & 2 & 82.63 \\
\hline 7 & 45.6 & $\begin{array}{l}\text { 1.3.6 Consider marketing, training and managerial } \\
\text { support }\end{array}$ & 10 & 16.52 \\
\hline 9 & 37.5 & $\begin{array}{l}\text { 1.3.7 Foster the development of community-based } \\
\text { tourism products }\end{array}$ & 1 & 82.76 \\
\hline 4 & 58.2 & $\begin{array}{l}\text { 1.3.8 Encourage visitors to spend more money in the } \\
\text { local economy }\end{array}$ & 9 & 24.59 \\
\hline 8 & 44.9 & 1.3.9 Encourage tour operators to be more innovative & 6 & 51.34 \\
\hline 4 & 58.2 & $\begin{array}{l}\text { 1.3.10 Consider using local entrepreneurs in } \\
\text { community initiatives }\end{array}$ & 5 & 57.10 \\
\hline 1 & 70.3 & $\begin{array}{l}\text { 1.3.11 Be transparent when reporting community } \\
\text { benefits }\end{array}$ & 7 & 47.96 \\
\hline 11 & 29.4 & $\begin{array}{l}\text { 1.3.12 Consider establishing targets to monitor } \\
\text { progress }\end{array}$ & 3 & 67.97 \\
\hline
\end{tabular}


benefits (1.3.11) in order to distribute the benefits and minimise the effects where, otherwise, one establishment dominates the tourism development process and in that way keeps all the potential benefits to itself.

For the future it is encouraging to see the commitment from product owners to identify projects that the enterprise can support that will benefit the poor (1.3.4). Poverty alleviation is a global problem, and it is particularly in rural areas like the VFD that tourism can contribute to reducing this. Assisting the development of local entrepreneurs with visitor feedback on their products (1.3.5) will allow the entrepreneurs to adapt their products to the market needs and in this way the product owners will foster the development of community-based tourism products by providing marketing and mentoring support (1.3.7) to entrepreneurs in the community.

The community-based approach between entrepreneur and product owner should foster a close relationship that should lead to the development of new products that provide complementary products for tourism enterprises (1.3.2). Especially the historically disadvantaged community will receive the opportunity to engage in the tourism sector (1.3.1). Developing business partnerships in which the community has a significant stake (1.3.3) will also contribute towards economic enhancement of the broader community.

\section{Marketing and product development}

Providing information about local services and attractions provided in the Dome, and encouraging tourists to use them (1.4.1) was rated as important to the product owners. The high rating that this aspect received is an indication that the product owners are committed to marketing the area to visitors. To consider cooperative advertising, marketing and the promotion of new and emerging products and attractions (1.4.2) was rated low, and for a community this small it might be a good idea to look into this opportunity. As the VFD is regarded by many as an adventure destination, it is not surprising to see the high rating that the product owners will foster the development of access opportunities for all visitors and potential visitors, regardless of physical or mental conditions (1.4.5).

Two factors that were not highly rated for the future (Table 4) are to consider developing and marketing fairly traded tourism products (1.4.4) and to ensure that the visual way in which the product is presented includes local cultural elements (1.4.3). Reasons for this might be that the product owners are already practising these two guidelines and one can thus expect them to rate these guidelines as low for the future. However, to rate fair trade tourism negatively might be regarded as a warning sign for the product owners. From Table 4 it is clear that curios constitute an important aspect for the VFD, but the community should be made aware that they should guard against unfair curio practices such as child labour and environmental degradation that might occur from "unfair" products.

From Table 4 it is clear that the VFD needs an aggressive TABLE 4

Marketing and product development

\begin{tabular}{|c|c|c|c|c|}
\hline \multicolumn{2}{|c|}{ PRESENT } & MARKETING AND PRODUCT DEVELOPMENT & \multicolumn{2}{|c|}{ FUTURE } \\
\hline & 40074 & Cronbach-alpha coefficient & & 98744 \\
\hline $\mathbf{R}$ & $\%$ & & $\mathbf{R}$ & $\%$ \\
\hline 3 & 35.88 & $\begin{array}{l}\text { 1.4.1 Provide information about local services and } \\
\text { attractions }\end{array}$ & 3 & 27.44 \\
\hline 5 & 22.43 & $\begin{array}{l}\text { 1.4.2 Consider cooperative advertising, marketing and } \\
\text { promotion }\end{array}$ & 1 & 59.60 \\
\hline 2 & 49.32 & $\begin{array}{l}\text { 1.4.3 Ensure that product presentation includes local } \\
\text { cultural elements }\end{array}$ & 4 & 8.41 \\
\hline 1 & 71.66 & $\begin{array}{l}\text { 1.4.4 Consider developing and marketing fairly traded } \\
\text { products }\end{array}$ & 5 & -0.52 \\
\hline 4 & 22.76 & $\begin{array}{l}\text { 1.4.5 Foster the development of access opportunities } \\
\text { for all visitors }\end{array}$ & 2 & 51.12 \\
\hline
\end{tabular}

marketing strategy in which product owners cooperate with each other as well as with the local community. This will provide access to smaller niche markets such as the physically challenged tourists who are not able to participate in adventure activities. Fair trade tourism products are part and parcel of ecotourism and are also closely related to sustainable development, and product owners cannot disregard this in the future.

\section{Equitable business opportunities}

Transparency and equity are central to sustainable development. As Florini (1999) puts it: “... transparency is always closely connected to accountability, the purpose of calls for transparency is to permit citizens, markets or governments to hold others accountable for their polities and performances. Thus, transparency can be defined as the release of information by institutions that is relevant to evaluating those institutions". In Table 5 equity and transparency are addressed and the results of the survey are presented in terms of how the product owners perceive these issues.

To set targets for increasing the proportion of the enterprise wage bill going to community within $20 \mathrm{~km}$ of the enterprise (1.5.4) was most highly rated at present and also for the future (Table 5). From this it is clear that product owners are currently employing locals where possible, but also regard it as an aspect in which the situation can be improved. Employment is a global problem, especially in rural communities where opportunities are scarce. However, with the commitment of product owners, as shown in Table 5, the problem might be reduced for future generations in the VFD.

From Table 5 it is clear that to develop transparent systems of sharing the benefits of tourism through equitable contracts. (e.g. tendering processes) (1.5.2) is rated relatively highly at present, and it is clear that the product owners feel that their current practices are effective. They also rated this guideline as important for the future, which indicates that there might be an increase in systems that will enhance the sharing of tourism benefits. One such system might be to advertise on the local website (http:// www.vredefortdome.co.za) any goods or services needed, and in that way local entrepreneurs might be able to render such services. An important consideration arises from the following, as entrepreneurs can be assisted to learn from their mistakes: when entering into agreements with the local community or emerging entrepreneurs ensure that the risk is equitably shared (1.5.3). If the product owners are willing to share the risk there might be an increase in entrepreneurial activities in the VFD area, and that will lead to the improvement of the community on many levels.

Product owners were aware of the issue of abusing their market power and imposing unfair commissions or pushing down prices inequitably (1.5.1), and in Table 5 the product owners also indicated that they will do more in the future to minimise market domination. The guideline that states to go beyond the bare minimum wage rate and invest in local staff - quality is dependent upon well-motivated staff (1.5.6) was left out of the statistical analysis because of the inconsistency when product

TABLE 5

Equitable business opportunities

\begin{tabular}{|c|c|c|c|c|}
\hline \multicolumn{2}{|c|}{ PRESENT } & EQUITABLE BUSINESS & \multicolumn{2}{|c|}{ FUTURE } \\
\hline & 46882 & Cronbach-alpha coefficient & & 00850 \\
\hline $\mathbf{R}$ & $\%$ & & $\mathbf{R}$ & $\%$ \\
\hline 5 & 11.84 & 1.5.1 Beware of abusing market power & 2 & 65.38 \\
\hline 2 & 43.03 & $\begin{array}{l}\text { 1.5.2 Develop transparent systems of sharing the } \\
\text { benefits }\end{array}$ & 3 & 52.03 \\
\hline 3 & 38.48 & 1.5.3 Ensure that the risk is equitably shared & 5 & 39.13 \\
\hline 1 & 44.66 & $\begin{array}{l}\text { 1.5.4 Set targets for wage bill to community within } 20 \\
\mathrm{~km} \text { of the enterprise }\end{array}$ & 1 & 88.07 \\
\hline 4 & 19.83 & $\begin{array}{l}\text { 1.5.5 Develop a community labour agreement with } \\
\text { targets }\end{array}$ & 4 & 51.01 \\
\hline
\end{tabular}


owners evaluated the guideline. The reason might be that the guideline addresses more than one issue, namely minimum wages and well-motivated quality staff. For future research, this guideline needs some contemplation in order to address the reliability quandary.

From the results it is clear that the environmental aspects are regarded as the most important. Product owners are committed to looking after the natural diversity in the area and to practise conservation strategies where possible. From an economic point of view it is clear that product owners are not always aware of the linkages between tourism and other economic activities in the area. For future benefits it is important that the product owners should practise activities that will reduce leakage out of the VFD and increase linkages with other economic partners. The social aspects were not rated as highly as one may have hoped for, but the future perspective looks prosperous. Tourism in the VFD is in a relatively healthy state at present and product owners are committed to increasing their positive performances in the future.

In the following section the measurement instrument that was used will be tested for reliability by making use of Cronbachs alpha coefficients.

\section{USE OF CRONBACHS ALPHA RELIABILITY COEFFICIENT FOR SUBSECTIONS}

The Cronbachs alpha reliability coefficient (Cronbach 1951) was calculated to determine whether the questions in each subsection constituted reliable measuring instruments for that particular subsection. From the literature it is clear that instruments with a Cronbachs alpha reliability coefficient of larger that 0.8 are very reliable, but that any instrument with a coefficient larger than 0.5 constitutes an acceptable measurement instrument (Anastasi 1988:817). All except one of the subsections (marketing and product development) are reliable measuring statements. The future perspective regarding the marketing and product development aspects are the only subsections that are not reliable and it will be interesting to observe and compare results in this regard in the future.

After the frequency analysis it was established that the measurement instrument is reliable, but the question remains: Do the results have any significance to the product owners in the VFD? In order to measure the relevance of the results in such a small population it is necessary to measure practically significant differences between present and future opinions. The reason for this calculation is that the population that was used in the survey is too small to generalise the results to all tourism product owners in South Africa.

\section{PRACTICALLY SIGNIFICANT DIFFERENCE BETWEEN THE PRESENT AND FUTURE OPINIONS}

In order to determine if there is a difference between the product owners' opinion regarding the importance of each guideline at present and for the future, the data for future importance was converted. Opinions of "important" or "very important" were recoded as 1 , while "not important" was recoded as 0 . The mean difference between these recoded future and present opinions was determined. Effect sizes were calculated to determine if there is a practically significant difference between the present and future opinions (see Steyn 2000:2). Effect sizes for dependent data (Steyn 2000) for each subsection were calculated by making use of the following formula:

$$
d=\frac{\bar{x}_{\text {diff }}}{s_{\text {diff }}}
$$

TABLE 6

Practically significant difference between the present and future opinions

\begin{tabular}{lccl}
\hline \multicolumn{1}{c}{ ECONOMIC ASPECTS } & $\bar{x}_{\text {diff }}$ & $S_{\text {diff }}$ & $\begin{array}{c}\text { EFFECT } \\
\text { SIZE }\end{array}$ \\
\hline $\begin{array}{l}\text { 1 Assessing economic impacts as a prerequisite to } \\
\text { developing tourism in VFD }\end{array}$ & 0.333 & 0.327 & $\mathbf{1 . 0 1 8}$ \\
2 Maximising local economic benefits & 0.271 & 0.410 & $\mathbf{0 . 6 6 1}$ \\
$\begin{array}{l}\text { 3 Ensuring that community is involved in and } \\
\text { benefits from tourism }\end{array}$ & 0.347 & 0.454 & $\mathbf{0 . 7 6 4}$ \\
4 Marketing and product development & 0.233 & 0.262 & $\mathbf{0 . 8 8 9}$ \\
5 Equitable business & 0.417 & 0.429 & $\mathbf{0 . 9 7 2}$ \\
\hline
\end{tabular}

where $\bar{x}_{\text {diff }}$ is the mean difference between future and present opinions and $s_{\text {diff }}$ the standard deviation of the difference between future and present opinions.

Cohen (1988) gives the following guidelines for the interpretation of the effect size in the current case:

(a) small effect: $d=0.2$,

(b) medium effect: $d=0.5$,

(c) large effect: $d=0.8$.

We consider data with $d \geq 0.8$ as practically significant, since it is the result of a difference having a large effect. These results are only practically significant for the population that participated in this survey. Table 6 presents the practically significant difference between the present and future opinions of product owners in the VFD.

From Table 6 it is apparent that all the social aspects are significant. The present situation compared with the increase in the future is of importance to the product owners. Some of the economic aspects are also practically significant, but none of the environmental aspects are significant. The reason for these environmental results is that the VFD is already developed and marketed as a nature-based tourism destination. Product owners in the area are already environmentally sensitive and the difference between the present and the future is not viewed as significant to this community. Thus, it is clear that if the VFD would like to be more sustainable, product owners should improve their social and economic aspects and continue with their environmental practices as at present.

\section{CONCLUSIONS}

This paper presents the frequency analysis of the guidelines tested on the VFD. The analysis was based on the present situation, regarding how product owners currently conduct their activities, as well as a future perspective. The future perspective indicated how product owners perceive an increase or decrease of each guideline, not the importance of each guideline, but rather how they perceive the increase or decrease of the specific guideline to be. After the frequency analysis was tabulated and discussed in the text, the reliability of the measurement instrument was tested. The results of Cronbachs alpha coefficients indicated that the instrument is reliable for the situation where it was utilised. The last part of the paper evaluated the practical significance of the results. In other words, the question as to whether the results mean anything for a community this small was addressed. Because of the size of the population it would have been senseless to use means as a measurement criterion and therefore the results were evaluated by using a special formula suited for this particular situation. Based on the results presented it is possible to formulate a strategy for sustainable tourism development in the Vredefort Dome area as a World Heritage Site.

For sustainable tourism development in the Vredefort Dome the following strategies are proposed on how tourism stakeholders can assist to achieve sustainability: 
- Follow an integrated approach to the planning and management of land resources. This implies that all stakeholders should work together and that the development of the area should take into consideration the economic, social and environmental impacts. In doing so, poverty alleviation can also be addressed in a sustainable manner. Stakeholders in the area include government, communities, product owners and investors.

- $\quad$ Protect and promote human health in the VFD.

- Promote education and training in the VFD.

- Promote sustainable human settlement development in the VFD area.

- Promote sustainable agriculture and rural development.

- Establish a system that guarantees supply that is in line with fair trade in tourism.

- $\quad$ Reduce leakages and other purchasing practices.

The results indicated that tourism stakeholders are willing to improve the present situation in the Vredefort Dome and to practise their businesses in a different way in the future. These changed practices entail that some strategic issues will need to be addressed, and the strategies mentioned above will give direction to this World Heritage Site to become more sustainable.

\section{REFERENCES}

Anastasi, A. 1988. Cronbachs Alpha Psychological testing (6th ed.). New York: Macmillan.

Bell, S. \& Morse, S. 1999. Sustainability indicators: Measuring the immeasurable. London: Earthscan.

Briedenhann, J. \& Wickens, E. 2004. Tourism routes as a tool for the economic development of rural areas - vibrant hope or impossible dream? Tourism Management, 25(1): 71-79, February.

Cohen, J. 1988. Statistical power analysis for the behavioural sciences (2nd ed.). Hillsdale: Erlbaum.

Contour project managers. 2002. Strategic development and management plan for the Vredefort Dome. Johannesburg: Grant Thornton Kessel Feinstein.

Cook, R.A., Yale, L.J. \& Marqua, J.J. 2002. Tourism - The business of travel (2nd ed.). London: Prentice Hall.

Cronbach, J.L. 1951. Coefficient alpha and internal structure of tests. Psychometrika, 16: 297-334.

Curtin, S. 2003. Whale-watching in Kaikoura: Sustainable destination development? Journal of Ecotourism, 2(3): 173195, December.

DEAT - See South Africa

Dwyer, L., Forsyth, P., Spurr, R. \& Vanho, T. 2003. Tourism's contribution to a state economy: a multi-regional general equilibrium analysis. Tourism Economics, 9(4): 431-448, December.
Finkler, W. \& Higham, J. 2004. The human dimensions of whale watching: An analysis based on viewing platforms. Human Dimensions of Wildlife, 9(2): 103-117, January.

Florini, A.M. 1999. Does the invisible hand need a transparent glove? The politics of transparency. Paper prepared for the annual World Bank conference on development economics, Washington, DC, 28-30 April 1999. Available: http://www. worldbank.org/research/abcde.papers.html [Accessed: 5 September 2002].

Han, Q., Dellaert, B.G.C., Van Raaij, F. \& Timmermans, H.J.P. 2003. Supporting tourist activity planning decisions from an urban tourism management perspective. Tourism Analysis, 8(2): 153-157.

IIED see International Institute for Environment and Development.

Inskeep, E. 1991. Tourism planning: An integrated and sustainable development approach. New York: Van Nostrand Reinhold.

International Institute for Environment and Development. 2000 Rural planning in South Africa: A case study. London: IIED.

Macdonald, R. \& Jolliffe, L. 2003. Cultural rural tourism Evidence from Canada. Annals of Tourism Research, 30(2): 307-322, April.

Murdoch, J. 1993. Sustainable rural development: towards a research agenda. Geoforum, 24(3): 25-241.

Murphey, P.E. 1985. Tourism: A community approach. New York: Routledge.

Oliver, T. \& Jenkins, T. 2003. Sustaining rural landscapes: the role of integrated tourism. Landscape Research, 28(3): 293307, July.

Reimold, W.U. \& Coney, L. 2001. The Vredefort Dome impact structure and directly related subjects: An updated biography. Johannesburg: Economic Geology Research Institute, University of the Witwatersrand.

Routledge, P. 2002. Resisting and reshaping the modern: Social movements and the development process. In Johnston, R.J., Taylor, P. J., Watts, M.J. \& Blackwell, O., (eds.). Geographies of global change. Remapping the world in the late twentieth century. London: Blackwell Publishing. p. 544

SAS Institute Inc., 2001. The SAS System for Windows Release 8.02 TS Level 02M0 Copyright $\odot$ 1999-2001 by SAS Institute Inc., Cary: USA.

Smith, V.L. 1977. Hosts and guests: The anthropology of tourism. Philadelphia: University of Pennsylvania Press.

South Africa. 1996. Department of Environmental Affairs and Tourism. The development of tourism in South Africa. Pretoria: Government Printer.

South Africa. 2002. Department of Environmental Affairs and Tourism. Guidelines for responsible tourism. Pretoria: Government Printer.

Steyn, H.S. (Jr.). 2000. Practical significance of the difference in means. Journal of Industrial Psychology, 26(3): 1-3. 